\title{
MANAGING SMES IN A TURBULENT CON- TEXT: A CASE STUDY FROM A KOSOVAN MANUFACTURING COMPANY
}

\author{
- Liridon Veliu, Mimoza Manxhari, Neshat Podvorica, Ejup Fejza, Valon \\ Hyesni
}

\begin{abstract}
The purpose of this paper is to present the influence of the management to the SMEs in the markets facing problems of economy consolidation. This paper seeks to explore how a particular manufacturing SME in Kosovo organizes its processes on the daily basis and the challenges that currently faces in a fragile competition. This research embraces a qualitative single case study methodology in the context of manufacturing SMEs. The data collection comprises fourteen interviews. We also conducted observation within the organization supplemented by analysing different documents in order to have triangulation that could increase validity and reliability.

This study helps theorists to emphasize more upon the criticality of manufacturing SMEs in building a strong case for future frameworks in order to demystify the overwhelming ideas that only managerial levels should be involved in the research domain for the case analysis especially in the manufacturing industry. Particularly in Kosovo where SMEs in the manufacturing sector are still struggling to recover and create a solid infrastructure for growth where the need for a broader integration in the analysis is indispensable in understanding the challenges and future alternatives of this sector. We intend helping managers, employees and wider practitioners to understand the importance of mutual task responsibilities; developing an integrated cooperation process; emphasizing the criticality of avoiding the orthodox approach of a managerial leading style, and transforming it into a new orthopraxy of ensuring that an internal employee involvement and participation is the key to articulating the necessary efforts of organizational success.
\end{abstract}

Keywords: manufacturing sector, doors and windows, SMEs, Kosovo, competition

JEL Classification: L6; MOO

\section{INTRODUCTION}

Manufacturing SMEs were mostly studied in western developed countries where the need for further knowledge was demanded (Tsai et al., 2007). Particularly in large economies, the importance of understanding this sector has massively received literature attention (Blackburn et al., 2004) perhaps because it is regarded as the backbone of jobs creation (Bae et al., 2011; Zheng et al., 2009). In this context, different authors pay more attention to investigating various aspects of manufacturing SMEs that affect management practices (Prouska \& Kapsali, 2011; Gherhes et al., 2016) including human resources (Clark, 1996), operation management (Brewster, 1999) supply chain management (Hoskisson et al., 2000; Selviaridis et al. 2016). With some exception Antonacopoulou \& Sheaffer (2014), Hoskisson et al. (2000), Prouska \& Kapsali (2011) that illus- 
trate the fact that in transition and peripheral economies, SMEs used to work under developed infrastructure as well as market conditions that influence business operation policies negatively. So, taking this into account and the limited knowledge on SMEs, particularly in Kosovo, with the exception of Krasniqi \& Mustafa (2016), Krasniqi \& Desai (2016) and their research on small firms' growth and drivers of high firms' growth respectively, manufacturing SMEs are still overshadowed in this part of the world.

We focused on observing the internal operation processes of doors and windows in Kosovo. We were more interested to know: How does Dela-Porta organize its operation processes? And what are the challenges that Dela-Porta face during the processes conducted? Investigating these questions would give us better knowledge after this research is done. It is the foundation from an exploratory perspective.

We found that the processes conducted enabled some chronological and systematic steps within the organization capture where Dela-Porta is searching to maintain its credibility in the market, such as dynamic routines, technology, technical knowledge, products quality and outsourcing policy. Likewise, technology helps the transformation stage of products including gloves that need to be drilled and polishing products that require technical knowledge during the entire phases. Furthermore, outsourcing policy is taking place as an operation strategy that keeps the raw material on an adequate level. Therefore, this research contributes by providing rich insights that trigger theorists to focus more upon the importance of manufacturing SMEs, and particularly on building frameworks where not only managers are overwhelmingly investigated, but employees' involvement and participation as well.

\section{LITERATURE REVIEW}

\section{Technological aspect of SMEs growth process}

Manufacturing SMEs in the process of announcing internal transformation initiatives of products and services are surrounded by strengths and vulnerabilities (Stern, 2009) particularly when facing highly stressful situations. A critical task and responsibility that manufacturing organizations face in the contemporary business environment is the demand for being able to integrate and manage the transformation processes in SMEs by using various frameworks and models (Garetti \& Taisch, 2012).

Garetti \& Taisch (2012) emphasize more the technological aspect, whereas Liu et al. (2013) put more attention to the supply chain as indicative mean on providing quick repair and maintenance services while minimizing costs, which ultimately influences SMEs structure through exploring the gaps that exist in the operationalizing tasks (Knott \& McKelvely, 1999) and it has effect on the increase of competitiveness of companies in the market.

The transformation process in SMEs is very much linked with a technological change, which in various times is perceived to increase the performance that helps organizations to sustain their operation activity by spreading knowledge in the last instance (Chen \& Yu, 2012; Ramdani et al., 2013). Specifically, using the latest technology in modernizing product and service processes is considered to be a demanding necessity in manufacturing organizations that insist on providing 
a flexible structure and conjoin coordination and interaction among employees and managers (Bocchino, 1993). In essence, technology is the cornerstone of manufacturing efficient functionality (Kirkhaug, 2010; Spinelli et al., 2013), a path of ensuring the automatic processes that reduces cost, and ensures long run of sustainable internal consistency (Blakçori et al., 2014), that continuously concerns the manufacturing sector during production stages that makes this case undoubtedly more valuable (Polites \& Karahanna, 2013).

\section{Knowledge as an important source of influencing SMEs processes}

Organizational knowledge creates the opportunity to influence proactively internal processes due products and services (Pousette et al., 2003). It particularly contributes toward employees' experience in different strategic relations that enrich the likelihood for improving employees' behaviour in task performance (García-Pont \& Nohria, 2002). So, in theoretical stance, knowledge is a conducive factor that helps organizations divest of complexity, instability, animosity and ambiguity toward embracing a new useful approach (Garetti \& Taisch, 2012) that determines organizational outcomes as an upshot of continuous improvements (Bingham \& Eisenhardt, 2011). As literature provides evidence that in operation sphere, particularly in the manufacturing context, knowledge is prioritized in enhancing the technical aspect of implementing tasks through socialization (Lazaric, 2000) where notions, ideas, concepts and thoughts are exchanged. This also helps in reducing fear (Greta \& Karahanna, 2013) as a preamble of practically implementing any service innovation in the context of SMEs (Harrigan et al., 2011). Therefore, knowledge is a helpful source of shaping manufacturing SMEs internal processes via a comprehensive effort of synchronized interaction between managers and employees (Reurer et al., 2002).

\section{Managers and employees' role and engagement in SMEs}

Furthermore, managers and employees' engagement in manufacturing SMEs is demanded especially in making a change during the crisis times where the need for long sustainable solutions is tectonically important. In this context, Chaterina \& Landeta (2013) emphasize the organizational impact of a broad integrated structure where managers and employees develop a new set of a cooperation process that speeds up the process of designing the strategy of developing SMEs growth policy. In this vein, organizations that do not manage to establish an organizational internal discourse by integrating managers as well as employees' voice in improving the internal operation activities during difficult times as guidance of the entire process (Schilke, 2007), will persistently face the consequences of uncertainty during the transformation processes (Farjoun, 2010). Therefore, Baumol (2002) approached this discussion by emphasizing the role of internal communication that contributes to SMEs. Moreover, this occurs through increasing the obtainable information when any form of uncertainty might appear and this creates the condition for more pragmatic and decent approaches due to employees' insecurity (Ritchie \& Brindley, 2005).

\section{METHODS}

\section{Organization's context of study}

Dela-Porta is a small and medium manufacturing company of polyvinyl chloride (PVC) and wooden doors and windows established in this industry in 1960. It is located $15 \mathrm{~km}$ in south 
from Pristina, the capital city of Kosovo. Dela-Porta is an inherited family business. The owner's father opened this business to create something different in the market. In the onset, the owner did use very few manufacturing machines to produce mainly wooden doors and windows and the core work was done by physical force. In 1990, the business was inherited by his son without changing the tradition, however, with almost profound internal transformation processes established. During all these years, the company was actively operating in this industry. Unfortunately, Dela Porta had a year off due to the situation created in the country during 1999. In April 2000 , the company started its activities almost from scratch, however, in the course of a period of 5 years, the owner managed to create a great capital that helped him invest in new business premises, built the headquarters in Pristina and imported the necessary equipment from Italy. At the same time, they managed to introduce a new cooperation initiative with a German company to supply with raw material for plastic doors and windows. They used to focus their core operations in wooden products like doors and windows, which lasted for decades. However, in the last 10 years, they have decided to expand their operations and offer plastic doors and windows as well. Despite that, the company offers other services like doors and windows installation services. Therefore, the reason for choosing this company is to present the average number of employees of this branch having been effective since 1990, in which the process of its management transformation may be noticed.

\section{Data Collection}

This study embraced a qualitative methodology to address and investigate the research questions. We requested to have a meeting with the owner where we emphasized the importance of this research by explaining its purpose and guaranteeing the confidentiality of information (Seidman, 1998) and emphasizing any ethical considerations regarding on the proposed study (Malhotra \& Peterson, 2001).

The data collection was conducted in a period of 4 months and included in depth interviews with the owner, director of the company, three managers of departments and nine employees.

Tab. 1 - Data derived from interviews

\begin{tabular}{|l|l|l|l|l|}
\hline Participants & $\begin{array}{l}\text { Date of } 1 \text { st } \\
\text { interview }\end{array}$ & Hours/min & $\begin{array}{l}\text { Transcribed } \\
\text { pages }\end{array}$ & Words \\
\hline Owner & $20 / 5 / 16$ & 55 & 7 & 4500 \\
\hline Director & $23 / 5 / 16$ & 60 & 8 & 5200 \\
\hline Administration Manager & $24 / 5 / 16$ & 63 & 8 & 4800 \\
\hline Engineering Manager & $28 / 5 / 16$ & 65 & 8 & 5530 \\
\hline Operation Manager & $30 / 5 / 16$ & 60 & 7 & 5054 \\
\hline Employee 1 & $31 / 5 / 16$ & 60 & 9 & 5400 \\
\hline Employee 2 & $2 / 6 / 16$ & 68 & 11 & 5532 \\
\hline Employee 3 & $5 / 6 / 16$ & 68 & 9 & 5650 \\
\hline Employee 4 & $5 / 6 / 16$ & 65 & 10 & 6800 \\
\hline
\end{tabular}




\begin{tabular}{|l|l|l|l|l|}
\hline Employee 5 & $7 / 6 / 16$ & 65 & 10 & 6500 \\
\hline Employee 6 & $9 / 7 / 16$ & 67 & 10 & 5800 \\
\hline Employee 7 & $13 / 6 / 16$ & 70 & 10 & 6900 \\
\hline Employee 8 & $14 / 6 / 16$ & 54 & 8 & 5230 \\
\hline Employee 9 & $16 / 6 / 16$ & 68 & 10 & 6700 \\
\hline
\end{tabular}

Manager and employees from different, but important functions were interviewed in order to ensure broader views and prospects (Selviaridis et al., 2016). In this organization, we have interviewed managers who were responsible for leading different functions like administration, operation and engineering. Each interview conducted lasted an average of one hour. It is likewise important to acknowledge that with managers we had repeated interviews. Moreover, semistructured interviews were obviously supplemented by other materials used like documents, notes, order receipts, etc. in order to have the triangulation and increased validity.

In this entire effort snowball, sampling was used to identify managers and employees who liked to participate in our research. However, after the first interviews, we decided to re-interview these people once more because we wanted to put more emphasis on manufacturing processes related to products and service.

Tab. 2 - Data derived from interviews

\begin{tabular}{|l|l|l|l|l|}
\hline Interviews & $\begin{array}{l}\text { Date of 2nd } \\
\text { interview }\end{array}$ & Hours/min & $\begin{array}{l}\text { Transcribed } \\
\text { pages }\end{array}$ & Words \\
\hline Owner & $12 / 8 / 16$ & 45 & 5 & 4300 \\
\hline Director & $10 / 8 / 16$ & 50 & 6 & 4423 \\
\hline Administration Manager & $11 / 8 / 16$ & 53 & 7 & 5102 \\
\hline Engineering Manager & $14 / 8 / 16$ & 61 & 8 & 5348 \\
\hline Operation Manager & $15 / 8 / 16$ & 64 & 8 & 5125 \\
\hline Employee 1 & $17 / 8 / 16$ & 67 & 8 & 5235 \\
\hline Employee 2 & $20 / 8 / 16$ & 60 & 7 & 4975 \\
\hline Employee 3 & $23 / 8 / 16$ & 62 & 8 & 4897 \\
\hline Employee 4 & $26 / 8 / 16$ & 50 & 6 & 4149 \\
\hline Employee 5 & $29 / 8 / 16$ & 55 & 8 & 5874 \\
\hline Employee 6 & $30 / 8 / 16$ & 54 & 7 & 5645 \\
\hline Employee 7 & $2 / 9 / 16$ & 59 & 9 & 6230 \\
\hline Employee 8 & $4 / 9 / 16$ & 63 & 8 & 5460 \\
\hline Employee 9 & $7 / 9 / 16$ & 65 & 9 & 5978 \\
\hline
\end{tabular}

This allowed us to observe how managers and employees do their tasks on daily basis. Part of the observation is joining official meetings with other members of staff that took place within the setting, and most importantly developing a new informal conversation with people attending these meetings. 


\section{Data Analysis}

The process of data analysis was based on four steps. First, in accordance with authors like Collis \& Hussey (2009) who suggest that when the researchers have a large amount of data to analyse, subsequently the primary step is to determine the "basis for selecting a sample" (p. 165). Then we followed up with coding units, for instance a research question (Miles et al., 2014) sometimes-specific word, character, item or theme that were found in the data transcription (Gummesson, 2000). Once the data units were determined, the researcher constructed a coding frame, which following Collis \& Hussey (2009) the coding unit was listed in the first column, by leaving space for the next step of the analysis of every single communication to be added in the horizontal axis. So, the data was organized categorically and chronologically, and reviewed repeatedly (Creswell, 2014).

\section{Tab. 3 - Interview Protocol}

\section{a. First Interview Protocol}

1. Could you tell us something about yourself?

2. What are the things you are doing here?

3. What is it like to work in manufacturing companies?

4. Could you tell us your tasks, duties and responsibilities?

5. Could you tell us something about the doors and windows as products?

6. What are the processes needed to be conducted in this respect?

7. What is unique to doors and windows?

\section{b. Second Interview Protocol}

1. Could you tell us a bit more why a lot of processes are best on repetition?

2. How are those processes interconnected with one another?

3. Why does technology make a difference in your sector?

4. Do you have any concern that technology is making jobs obsolete?

5. Why do those processes require technical knowledge?

6. Why is almost everything based on technical jargon of conducting the work here?

7. Could you explain a bit more the idea of outsourcing some processes?

8. Is it difficult to work with another company in performing some requests?

9. Why do you think this operation strategy is the right one for the company?

10.What are some of the steps that you will take in the future due to this industry? 


\begin{tabular}{|l|l|}
\hline \multicolumn{2}{|l|}{ c. Axial Coding and Open Coding } \\
\hline $\begin{array}{l}\text { Core themes / } \\
\text { axial codes }\end{array}$ & Open codes \\
\hline 1. Routines & $\begin{array}{l}\text { "Door Size"; "Window Size"; "Size Measurements"; "Dimension } \\
\text { Measurements"; "Color"; "Mechanisms" "Wood Types" }\end{array}$ \\
\hline 2. Technology & $\begin{array}{l}\text { "Technical Knowledge"; "Gloves Drilling"; "Quality Products"; } \\
\text { "Change Processes"; "Wood Drying Machine" }\end{array}$ \\
\hline 3. Processes & $\begin{array}{l}\text { "Packaging Processes"; "Installment Processes"; "Polishing Proc- } \\
\text { esses"; "Maintenance Process"; "Outsourcing Processes" }\end{array}$ \\
\hline
\end{tabular}

Secondly, the data collection was a subjected to research in the next stage, the content analysis. Bryman \& Bell (2007) emphasize the fact that the content analysis is an adequate technique in research methods for analysing the data. The significance of content analysis is well recognized as a very accurate technique that provides the possibility to replicate the usable approach of interpretation from the unstructured actual data to the rational and comprehensive structure (Mayring, 2004; Schreier, 2012). Furthermore, in this research, the data analysis subjected to the content analysis was based upon Mayring (2004) and we suggested steps: First, we defined the information derived from interviews.

Secondly, the data collection was analysed. Thirdly, the information obtained from research participants was formally characterized by emphasizing the recording process of the data analysis. Fourthly, the decision was made following the direction of the analysis.

The data were analysed by using practical and useful software that provides the necessary tools and is likewise dedicated to a qualitative research called NVivo. This program allows the researcher to enter the code names in the initial stage or at latter stage (Creswell, 2014).

Finally, the researchers pursued a critical review of identifying the literature that most fits to the discussion derived on SMEs manufacturing organizations in order to canalize the efforts in enhancing the theoretical contribution. This approach facilitated the analysis because it helped the researchers recognize how the data collection suit to SMEs manufacturing. Therefore, the idea behind this argument is to identify the present theory on the topic and to expand the odds for generating a new theory out of the findings (Mitchell, 1983).

Furthermore, taking into account the recommendations that are provided by many authors, we need to emphasize that four criteria for evaluating case study research were used during the entire research process, namely: reliability, internal validity, construct validity and external validity (Barratt et al. 2011; Voss et al. 2002).

\section{Findings}

Dela-Porta is a single company being engaged in a particular manufacturing segment like doors and windows. It focuses on making an order system. So, the process starts from the order taking, continues with preparing and testing products and closes when the customer accepts the final product. “... The very beginning stage starts by taking the order from customers. This phase is considered as gathering and processing information. Then we put all the necessary data into the 
system (ERP) where preliminary material and cost is calculated.” (Operation Manager) “... The production manager is immediately informed through ERP and a further detailed explanation is performed. Then, the system is checked to see if all materials needed are in inventory depot and the next stage of process continues" (Operation Manager)

After gaining the information from customers following their needs, the production manager continues its work by expanding the scope of information regarding measurement, and material to be used and other features requested by customers as mentioned by the following manager: "... The next step is to make the necessary measurements. After gathering information about the dimensions, then the type of materials to be used and other features are discussed. Summarizing all the work that has to be done, the preliminary price is communicated toward the customer. Preliminary price is always communicated to the client's premises in order to add or eliminate any extra feature or anything related. The first stage of the process ends with sign in the order contract" (Production Manager)

However, during our conversation, we understood that wood products demand more work and steps to follow than plastic products: “... For both types of products, the process is roughly the same, but there is a difference for wood products which require more work and therefore more steps in the process. This phase is associated with a lot of measurements and an extensive usage of machinery" (Instalment Employee). This is well articulated and demonstrated in these processes conducted, as it demonstrates the operationalization of the organizational structure.

\section{Narrative 2}

In the discussion with managers and employees, we were able to understand that despite the small differences between wood and plastic steps to be followed, the production stage is particularly important. “... This is the stage when the errors must be minimized, since what is cut cannot be returned to the previous form. This phase holds great importance for the process, especially regarding sophisticated technology and technical knowledge. The ERP and machinery are critical, followed by people and production where responsibility for defects exists" (Operation Manager)

The following quote illustrates this: “... Despite cutting profiles in the size defined, the refining and transformation phase comes. At this stage, technology for wood products starts carving and shaping the process. Then, it continues with the stages of transformation where the channels for mechanisms are prepared, holes for gloves and other parts are drilled. The same process occurs for plastic windows except one difference that they do not need to be polished at the beginning" (HR Manager)

Plenty of time, doing this created monotony when performing the job, however, these processes have to be done otherwise you could easily take the wrong direction: “... After drilling and shaping, it continues with the next stage of further cutting and fixing. In this phase, are involved some cutting machines mainly to achieve the required dimensions that match. This phase requires more technical knowledge. There are often boring tasks to be done, you perhaps could notice it (smiles), but we have to go through them all the time, there is no option left" (Production Manager) 
Particularly measurements related to angels of doors and windows are important in order to match where basically not only the functionality of the product depends on but it could also be excruciating to employees because additional work needs to be done and consequences occur. “... So, after second cutting and fixing, we proceed with the phase of assembling of parts. This phase is characterized by a series of measurements to be taken, as because a final form of the structure of the door or window made of either wood or plastic is given. In this stage, angles of windows and doors are very important to match, because the functionality of the product depends on this. It is the most stressful aspect of the job, because you might face the consequences of failure" (Operation Manager).

Rationalizing the entire process that is constructively associated with enhancing technical knowledge articulates the need for the second stage where this knowledge is more required to capitalize the benefits of this job.

\section{Narrative 3}

During our discussion with managers and employees, it was clear that the process requires plenty of steps before the finalizing stage of doors and windows. This process actually is exclusive for wooden doors and windows, while the PVC products do not need to be painted. This phase also has some sub -phases that should be undertaken. After drying the first longer of colour, the product takes the final sanding and second longer of the final painting. “... Quality is essential for our business in today's competitive environment. These aspects of wood and plastic quality are very important to preserve our customization first, and second, to move on with this production process toward services. We make sure that all the wood and plastic doors and windows made undertake certain processes till the final stage" (Production Manager)

This knowledge, especially for carving and engravings, is tacit knowledge transferred through generations. These quotes illustrate this issue further: “... Usually, when they build their houses, customers are not aware what kind of windows fit best, where they can be installed, should be fixed or should be casement or any other special type. In this case, the expertise gained and the knowledge transferred from the past help the company's efforts to exceed customer expectations” (Managing Director). “... So, knowledge transfers to explicit knowledge to solve problems and provide solutions to be considered especially when taking measurements and during the installation and decoration phase of processes implemented that require a high quality" (Instalment Employee).

In order to achieve this target, the company also possesses the wood dryer system to ensure the quality of wood products. This technology in particular is supposed to give some competitive advantages in the early stages of the process. As the production manager said: “... You can do a great job, but since you put low-quality materials into the process, the final product will fail" (Production Manager)

Major reason among others provided is the care to protect the product from scratching throughout transportation, which ensures maintaining high quality and better perception by the customer before the instalment process takes place. “... The installation process is part of service that we as a company offer. Customers can participate in the installation process and make any objection and suggestion." (Instalment Employee) 
This also implies that feedback is expected at any stage 'timely and warmly', which emphasizes social values embraced. “... We usually make clear to our customers during the instalment processes that we are open for any discussion during our work. I do remember that once it happened that one of our customers was constantly watching us, but we did not mind at all, because we knew in advance that he used to do the same job abroad for more than 15 years." (Instalment Supervisor).

\section{Narrative 4}

During the whole process of instalment, Dela-Porta created a policy when it comes to wood and plastic windows something that is not applicable to wood and plastic doors. Among other activities during the service processes in specific cases, the order for glass is made for certain products, following to customer requirements. It also takes a significant amount of time because you need to have the staff prepared that needs an additional training and investment, it likewise saves a lot of effort through arranging activities like transportation and installation. “... Yes, we have some service processes that we outsource but there are not too many. We signed before an agreement with Delta-Fabric three years ago, which I would say is the best company for glass production in our country. Therefore, when we have customers that require some sort of wood or plastic windows mostly from western world, we take their ideas." (Operation Manager)

This helps the company keep the inventory level or raw materials on an adequate level. So, following this rationale of outsourcing, it is supposed to help the company decide about the final prices of special products and then send the order to a contractual company. Moreover, as part of the final services provided, rechecking after the instalment process is done. "... After couple of days, a team of workers go and check at the customer premises to see whether everything is up to standard with the glass and test once again the functionality of the product. Then, the last phase is signing the contract confirming that the customer accepts the final product" (Production Manager)

This stage is a bit more complicated since wood as well as PVC windows should be the exact measurement and mechanism models, in which a recheck is useful to make sure that mechanisms of opening and closing are perfectly working. “... Actually, you are right, but do not forget the fact that this is our task (Smiles)! Holding a manager position is a demanding task. But, to come back to your question, yes, it requires our involvement where some standard practices are pretty unsuccessful” (Operation Manager). “... Well, you know, I experienced that when you constantly raise the issue of (re) designing a particular process, you create the momentum by default, and this will rarely reflect on any emerging consequences because you gave the aspirin to the patient before the headache collapsed.” (Managing Director)

This could be illustrated by the following quote: “... Well, certainly you (refers to himself) as a manager are in charge for sorting some clinical problems occurring perhaps on daily basis. Like it or dislike it, this is the way how it is (smiles). In this discussion, we have to go through the same steps continuously, which repetition is what makes us worried. However, in our case, the idea is to initiate the right means so that the final product is accepted by trying to minimize the damages as much as possible." (Production Manager) 


\section{DISCUSSION}

From the very beginning of its foundation, Dela-Porta is a manufacturing organization. The processes conducted within the organization shape the core functionality of this business for many years. Despite various aspects of diverging and shaping internal processes, it is important to emphasize that almost everything conducted within this manufacturing organization is continuously repeated and performed via dynamic routines (Feldman \& Pentland, 2003). This illustrates the point that routines in organizations contain some inextricable steps that are synchronized. In other words, routines work in harmony in order to avoid any dysfunctional process that causes negative effects in articulating the need for functional internal working system (Blakçori \& Psychogios, 2015; Pentland \& Feldman, 2005). Therefore, there is a wide range of automatisation tasks followed by performing routines in the integrated chain of processes operated (Gersick \& Hackman, 1990). In this vein, managers and employees acknowledge the importance of routines as knowledge holder as well as operations are being practiced by different organizational actors (Feldman \& Pentland, 2003), because it helps the organization sophisticate its operation through sharing the knowledge between members.

The knowledge plenty of times derived from routines is demonstrated as a key component in articulating the importance of embracing the adequate technology in production functions (Maitilis, 2005) - particularly in some processes linked with transformation processes where employees are engaged in processing gloves that is needed to be drilled or polished both for wooden and plastic products. This needs not only the latest technology but at the same time, technical knowledge (Willis et al, 2009). This research demonstrates that Dela-Porta captured the importance of technology and technical knowledge, because they intend to meet the standards integrated at the core of organizational processes (Battilana et al., 2009). So, on various occasions, the sense of investment in transforming a manufacturing interface is externally urged and created (Blakçori, 2014, Wilhelm \& Bort, 2013). In this respect, the technical knowledge in this segment is seen to push employees not only to complete their duties quickly, but also to create an internal sophisticated linguistic discourse due to generalizing and institutionalizing particular meaning and rules in production processes (Tsoukas \& Chia, 2002). This perhaps forms the present approach of organizational members' inclination regarding processes conducted (Westphal \& Zajac, 1998) through recognizing technology and technical knowledge to be able to use it as a critical mean in operation processes.

In the meantime, Dela-Porta ensured that its services contain different steps followed and implemented in chronological order. It was obvious that particular attention was paid to details because this determined not only the quality of the products, but at the same time, consequences emerged (Miettinen \& Virkkunen, 2005).

This occurs especially in this industry because the wood and plastic customization is high and for Dela-Porta, it is important to understand this customization in details as it ensures the ongoing presence in the market (Westphal \& Zajac, 1998). A part of this is demonstrated during the installation and maintenance where particular attention was usually paid before and after the services provided. This also illustrates the tenacity that manufacturing companies have to carry on in order to increase the flexibility and dynamism in offering wood and plastic products (Willis et al. 2009). 
Therefore, for SMEs, it is crucial to find alternatives in fulfilling their incapability on various products demanded in order to maintain their competitiveness. This demonstrates a strong knowledge competency in dealing proactively with some processes that so far seem not to be possibly implemented within the core functions of processes conducted (Klarner \& Raisch, 2013).

\section{CONCLUSION}

In this research, we found that the processes conducted within this organization capture some chronological and systematic steps where the organization is searching to materialize and maintain its credibility in the market such as dynamic routines, technology, technical knowledge, products quality and outsourcing policy.

Dela-Porta is considered to be a great example of maintaining its inherited operation business founded decades ago in Kosovo. At the same time, technology is certainly one important source of Dela-Porta's significant development in this industry. Moreover, Dela-Porta put significant effort into enriching the quality of their products by introducing the wood dryer system to ensure the quality of wood products. Furthermore, outsourcing policy has been taking place for a long time as an operation strategy, which helps Dela-Porta minimize the errors as well as keep the raw material on an adequate level. These processes enable Dela-Porta to increase its production speed and to become more competitive in the market.

Therefore, this research paper contributes toward a critical manufacturing approach of studying and understanding the causes, factors and modalities that forcefully push forward the processes due to products and services in a SME manufacturing organization. However, in rich manufacturing studies, cases provided and in depth analyses should be taken seriously as well as rich insights derived should be considered worthily implemented. In theoretical terms, this study helps theorists build more upon the criticality of manufacturing SMEs in making a strong case for future frameworks in order to demystify the overwhelming ideas that only managerial levels should be involved in the research domain for case analyses especially in the manufacturing industry. Particularly in Kosovo where SMEs in the manufacturing sector are still struggling to recover and strive to create a solid infrastructure for growth where the need for a broader integration in the analysis is indispensable in understanding the challenges, problems and future alternatives. Moreover, a high competition has its effect on employees not providing the opportunity to develop their creativity due to minimization of costs.

\section{Acknowledgment}

We want to express our greatest gratitude to Feim Blakçori for his advice and guidance in the previous drafts. We do appreciate everything that he did in order to make this happen.

\section{References}

1. Antonacopoulou, E. P. \& Sheaffer, Z. (2014). Learning in Crisis Rethinking the Relationship Between Organizational Learning and Crisis Management. Journal of Management Inquiry, 23(1), 5-21. https://doi.org/10.1177/1056492612472730.

2. Bae, J., Chen, S. J \& Rowley, C. (2011).From a paternalistic model towards what? HRM trends in Korea and Taiwan. Personnel Review, 40(6), 700-722. https://doi.org/10.1108/004834811111 69643. 
3. Barratt, M., Choi, T. \& Li, M. (2011). Qualitative case studies in operations management: Trends, research outcomes and future research implications. Journal of Operations Management, 29(4), 329-342. https://doi.org/10.1016/j.jom.2010.06.002.

4. Battilana, J., B. Leca. \& Boxenbaum, E. (2009). How actors change institutions: Towards a theory of institutional entrepreneurship. Academy of Management Annals, 3(1), 65-107.

5. Baumol, W. J. (2002). The free-market innovation machine. Analyzing the growth miracle of capitalism. Princeton: Princeton Univ. Press.

6. Bingham, C. B. \& Eisenhardt, K. M. (2011). Rational heuristics: the 'simple rules' that strategists learn from process experience. Strategic Management Journal, 32(13), 1437-1462. http://onlinelibrary.wiley.com/doi/10.1002/smj.965/abstract.

7. Blackburn, J. D., Guide, V. D. R., Souza, G. C., \& Van Wassenhove, L. N. (2004). Reverse supply chains for commercial returns. California Management Review, 46(2), 6-22.

8. Blakçori, F. M., Fejza, E. \& Hyseni, V. N. (2014). The Implications/ Reflections of European Economic Integration in Kosovo's Business Environment Managers' Attitude towards European Economic Integration Process. International Journal of Business and Management, 9(2), 222-234. http://dx.doi.org/10.5539/ijbm.v9n2p222.

9. Bocchino, R. (1993). Are you planning the future or fixing the past? Journal of Staff Development, 14(1), 48-52.

10. Brewster, C. (1999). Strategic human resource management: the value of different paradigms. Management International Review, 39(3), 45-64. https://doi.org/10.1007/978-3-32290993-0_5.

11. Bryman, A. \& Bell, E. (2007). Business research methods. Second edition. Oxford University Press: New York.

12. Charterina, J. \& Landeta, J. (2013). Effects of Knowledge-sharing Routines and Dyadbased Investments on Company Innovation and Performance: An Empirical Study of Spanish Manufacturing Companies. International Journal of Management, 30(1), 20-39.

13. Chen, D. \& Yu, Sh. (2012). Organizational Routines, Organizational Commitment, and Performance. Asia Academy of Management-Conference-Doctoral Consortium, 1(7), 1-14.

14. Collis, J. \& Hussey, R. (2009). Business Research. A Practical Guide for Undergraduate \& Postgraduate Students. Polgrave: Macmillan.

15. Creswell, J. W. (2014). Research Design. Qualitative, Quantitative, and Mixed Methods Approaches. (4th ed.). Limited: Sage.

16. Farjoun, M. (2010). Beyond Dualism: Stability and change as a duality. Academy of Management Review, 35(2), 202-225.

17. Feldman, M. S. \& Pentland, B. T. (2003). Reconceptualizing organizational routines as a source of flexibility and change. Administrative Science Quarterly, 48(1), 94-118.

18. Garcia-Pont, C. \& Nohria, N. (2002). Local versus globalmimetism: The dynamics of alliance formation in the automobile industry. Strategic Management Journal, 23(4), 307-321. https://doi.org/10.1002/smj.225. 
19. Garetti, M. \& Taisch, M. (2012). Sustainable manufacturing: trends and research challenges. Production Planning \& Control, 23(2-3), 83-104. https://doi.org/1080/09537287.2 011.591619 .

20. Gersick, C. J. \& Hackman, J. R. (1990). Habitual routines in task-performing groups. Organizational Behaviour and Human Decision Processes. 47(1), 65-97. https://doi. org/10.1016/0749-5978(90)90047-D.

21. Gherhes, C., Williams, N., Vorley, T. \& Vasconcelos, A. (2016). Distinguishing microbusinesses from SMEs: a systematic review of growth constraints. Journal of Small Business and Enterprise Development, 23(4), 939-963. https://doi.org/10.1108/JSBED-05-2016-0075.

22. Gummesson, E. (2000). Qualitative Methods in Management Research. (2nd ed.). Thousand Oaks: Sage.

23. Harrigan, P., Ramsey, E. \& Ibbotson, P. (2011). Critical factors underpinning the e-CRM activities of SMEs. Journal of Marketing Management, 27(6), 503-529. https://doi.org/10.1080/ 0267257X.2010.495284.

24. Hoskisson, R. E., Eden, L., Lau, C.M., \& Wright, M. (2000). Strategy in emerging economies. Academy of Management Journal, 43(3), 249-267. https://doi.org/10.2307/1556394.

25. Kirkhaug, R. (2010). The Relations between social and formal working conditions and charisma. Organization Management Journal, 7(3), pp. 229-239. https://doi.org/10.1057/ omj.2010.27.

26. Klarner, P. \& Raisch, S. (2013). Move to the beat-rhythms of change and firm performance. Academy of Management Journal, 56(1), 160-184.

27. Knott, A. M. \& McKelvey, B. (1999). Nirvana efficiency: a comparative test of residual claims and routines. Journal of Economic Behavior \& Organization, 38(4), 365-383. https://doi. org/10.1016/S0167-2681(99)00016-5.

28. Krasniqi, B. \& Desai, S. (2016). Institutional drivers of high-growth firms: country-level evidence from 26 transition economies. Small Business Economics, 47(4), 1075-1094. https:// doi.org/10.1007/s11187-016-9736-7.

29. Krasniqi, B. \& Mustafa M. (2016). Small firm growth in a post-conflict environment: the role of human capital, institutional quality, and managerial capacities. International Entrepreneurship and Management Journal, 12(4), 1164-1207. https://doi.org/10.1007/s11365016-0384-9.

30. Lazaric, N. (2000). The role of routines, rules and habits in collective learning: Some epistemological and ontological considerations. European Journal of Economic and Social Systems, 14(2), 157-171. https://doi.org/10.1051/ejess:2000115.

31. Liu, P, S. Huang, H., Mokasdar, A., Zhou, H. \& Hou, L. (2014). The impact of additive manufacturing in the aircraft spare parts supply chain: supply chain operation reference (scor) model based analysis. Production Planning \& Control, 25(13-14), 1169-1181. https://doi/ abs/10.1080/09537287.2013.808835.

32. Malhotra, N. K. \& Peterson, M. (2001). Marketing research in the new millennium: Emerging issues and trends. Marketing Intelligence and Planning, 19(4), 216-235. https://doi. org/10.1108/EUM0000000005560. 
33. Mayring, P. (2004). Qualitative Content Analysis. London: Sage.

34. Miettinen, R. \& Virkkunen, J. (2005). Epistemic objects, artefacts and organisational change. Organization, 12(3), 437-456. https://doi.org/10.1177/1350508405051279.

35. Miles, M. B., Huberman, M. A. \& Saldana, J. (2014). Qualitative Data Analysis. (3d Edition). USA: Sage.

36. Mitchell, J. C. (1983). Case and Situation Analysis. Sociological Review, 3, 186-211. https://10.1111/j.1467-954X.1983.tb00387.x.

37. Pentland, B. T. \& Feldman, M. S. (2005). Organizational routines as a unit of analysis. Industrial \& Corporate Change, 14(5), 793-815. https://doi.org/10.1093/icc/dth070.

38. Polites, G. L. \& Karahanna, E. (2013). The embeddeness of information systems habits in organizational and individual level routines: development and disruption. MIS Quarterly, $37(1), 221-246$.

39. Pousette, A., Jacobsson, C., Thylefor, I. \& Hwang, C. P. (2003). The role of feedback in Swedish human service organizations. Community, Work \& Family, 6(3), 245-268. https:// doi/abs/10.1080/1366880032000143447.

40. Prouska, R. \& Kapsali, M. (2011). Business and Management Practices in Greece - A Comparative Context. Palgrave Macmillan, London.

41. Ramdani, B., Chevers, D. \& Williams, D. A. (2013). SMEs' adoption of enterprise applications: A technology-organisation-environment model. Journal of Small Business and Enterprise Development, 20(4), 735-753. https://doi.org/10.1108/JSBED-12-2011-0035.

42. Ritchie, B. \& Brindley, C. (2005). ICT adoption by SMEs: Implications for relationships and management. New Technology. Work and Employment, 20(3), 205-217. https:// doi/10.1111/j.1468-005X.2005.00154.x.

43. Schilke, O. S. (2007). Organizational Routines as Alliance Capabilities: The Missing Link. Academy of Management Annual Meeting Proceedings, 1-6.

44. Seidman, I. (1998). Interviewing as qualitative research. A guide for researching in education and the social sciences. New York: Teachers College Press.

45. Selviaridis, K., Matopoulos, A., Szamosi, L. \& Psychogios, A. (2016). Reverse resource exchanges in service supply chains: The case of returnable transport packaging. Supply Chain Management: An International Journal, 21(3), 381-397. https://doi.org/10.1108/SCM-072015-0265.

46. Spinelli, R., Dyerson, R. \& Harindranath, G. (2013) IT readiness in small firms. Journal of Small Business and Enterprise Development, 20(4), 807-823. https://doi.org/10.1108/JSBED-012012-0012.

47. Stern, E. K. (2009). Crisis Navigation: Lessons from History for the Crisis Manager in Chief. An International Journal of Policy, Administration, and Institutions, 22(2), 189-202. https:// doi/10.1111/j.1468-0491.2009.01431.x.

48. Tsai, C., Sen Gupta, S. \& Edwards, P. (2007). When and why is small beautiful? The experience of work in the small firm. Human Relations, 60(12), 1779-1807. https://doi.org/10.1177 /0018726707084914. 
49. Tsoukas, H. \& Chia, R. (2002). On organisational becoming: Rethinking organisational change. Organizational Science, 13(5), 567-582. https://doi.org/10.1287/orsc.13.5.567.7810.

50. Voss, C., Tsikriktsis, N. \& Frohlich, M. (2002). Case research in operations management. International Journal of Operations and Production Management, 22(2), 195-219. https://doi. org/10.1108/01443570210414329.

51. Westphal, J. D. \& Zajac, E. J. (1998). The symbolic management of stockholders: Corporate governance reforms and shareholder reactions. Administrative Science Quarterly, 43, 127-153. https://doi.org/10.2307/2393593.

52. Wilhelm, H. \& Bort, S. (2013). How managers talk about their consumption of popular management concepts: Identity, rules and situations. British Journal of Management, 24(3), 428-444. doi/10.1111/j.1467-8551.2012.00813.x.

53. Willis, A., Deane, F. \& Coombs, T. (2009). Improving clinicians' attitudes toward providing feedback on routine outcome assessments. International Journal of Mental Health Nursing, 18(3), 211-215. https://doi.org/10.1111/j.1447-0349.2009.00596.x.

54. Zheng, C., Morrison, M. \& O’Neill, G. (2006). An empirical study of high performance HRM practices in Chinese SMEs. The International Journal of Human Resource Management, 17(10), 1772-1803. http://www.tandfonline.com/doi/abs/10.1080/09585190600965282.

\section{Contact information}

Liridon Veliu, PhD Candidate

University of Tirana, Faculty of Economics;

University of Prishtina "Hasan Prishtina", Faculty of Economics

Rr. "Agim Ramadani" p.n., 10000 Prishtinë, Kosovo

Tel: +381(0)38228 966; E-mail: liridon.veliu@uni-pr.edu

Prof. Assoc. Dr. Mimoza Manxbari

University of Tirana, Faculty of Economics

Rektorati, Sheshi "NënëTereza", Nr. 183, Tiranë, Albania

E-mail:mmanxhari@yahoo.com

Neshat Podvorica, PhD Candidate - corresponding author

University of Prishtina "Hasan Prishtina", Faculty of Economics

Rr. "Agim Ramadani” p.n., 10000 Prishtinë, Kosovo

Tel: +381(0) 38228 966; E-mail:podvorica.neshat@gmail.com

Prof. Ass. Dr. Ejup Fejza

Dean Universum College, Prishtina, Kosovo

St. NikePrelaj, Objektii "Beni Dones" Prishtinë, Kosovo

Tel: +377(0) 44505662; E-mail: ejup.fejza@universum-ks.org

Valon Hyseni

MSc University of Prishtina "Hasan Prishtina", Faculty of Economics

St. Agim Ramadani” p.n. 10000 Prishtinë, Kosovo

Tel:+377 (0) 44787195; E-mail:valonhyseni@hotmail.com 